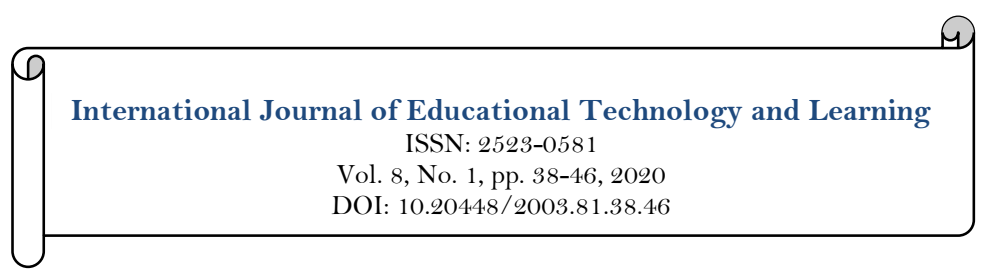

\title{
Effect of a Course on Educational Tools on Students' Attitude and Digital Literacy Skills
}

\author{
Ebrahim Samani ${ }^{1}$ \\ Raziyeh Bagheripour ${ }^{2}$ \\ Nooreen Noordin ${ }^{3 *}$
}

'Assistant Professor, Department of Foreign Languages, Higher Education Complex of Bam, Bam, Iran.

${ }^{2}$ Vising Lecturer, Department of Foreign Languages, Higher Education Complex of Bam, Bam, Iran.

${ }^{s}$ Senior Lecturer, Department of Language and Humanities Education, Universiti Putra Malaysia (UPM), Malaysia.

Email:nooyeen@yahoo.com

\begin{tabular}{l|l}
\multicolumn{3}{c}{ Abstract } & \\
This paper aimed at evaluating the effect of a course on educational tools on the & Keywords: \\
participants' digital literacy and collecting information on their attitude toward & Digital literacy \\
these tools and their pedagogical use as the result of attendance in this course. & Students' attitude \\
There were 15 participants in this study who attended the one-month course in & Edublogs \\
one of the charity summer schools in Bam, Iran. The content of the course included & Treatment. \\
topics like tagging, cyber threats, presentation tools, back up, creating video clips & \\
and so forth. Analysis of the results showed that there was a significant difference & Licensed: \\
in digital literacy scores and attitudes of students between pre and posttests. A & This work is licensed under a \\
review of the participants' projects and activities in Edublogs demonstrated that & Creative Commons Attribution 4.o \\
the participants were able to easily adapt technologies in creating different & License. \\
artifacts. The findings of this study provide insight to educators in their task of & Publisher: \\
increasing digital literacy in not only society but also among students. & Scientific Publishing Institute \\
& Accepted: 9 April 2020 \\
& Published: 27 April 2020
\end{tabular}

Funding: This study received no specific financial support.

Competing Interests: The authors declare that they have no competing interests.

\section{Introduction}

It cannot be denied that the lives of people are surrounded by digital tools that constantly change and the knowledge of these tools and the issues related to using them is a necessity for all walks of life. Knowledge of digital tools or the so-called digital literacy was originally introduced by Gilster (1997). The literature, however, is replete with different definitions of the concept of digital literacy (Eshet, 2004; Gilster, 1997; Inoue, Naito, \& Koshizuka, 1997; McClure, 1994; Neelameghan, 1995; Ng, 2012). Gilster simply defines it as the ability to understand and use information from diverse digital resources. It is argued that new generation is so well versed in using digital tools that they are sometimes referred to as "millenials" (Howe \& Strauss, 2009), " net generation” (Oblinger \& Oblinger, 2005; Tapscott, 2008) "homo zappiens" (Veen \& Vrakking, 2006), “instant messaging generation” (Lenhart, Rainie, \& Lewis, 2001), “ new millennium learners” (Pedró, 2007), or "digital natives" (Prensky, 2001). Even though the digital nativity of Prensky was seriously disputed in most of its underlying tenets like the existence of a difference in the structure of the brain between individuals born in a certain era and those before that, it is agreed that the new generation is technocomfly or techno savvies. However, it is discussed that if the young generation is not introduced to educational technologies, they will not necessarily think or know about them. To the same extent that society is 
responsible to educate its people, the new generation need to be nurtured into using digital tools educationally. Exploring different features of a new technology through the habit of " try and error" may help to acquire the necessary skills for social networking or other entertainment tools (Ito et al., 2009). However, it may not help digital natives to access, find information and use educational technologies if they are not introduced to these technologies and learn how to use them to address their needs. Beliefs and attitudes are also considered so crucial in the process of learning a language in different contexts that they might change the process and outcome (Kalaja \& Ferreira, 2003). The rapid growth of educational technology and the tendency to introduce them into classrooms has had a positive effect on students' attitudes. Indeed, learners' beliefs and opinions act like a filter and only allow the education that is perceived as interesting and beneficial. As a result, educators should plan their classroom activities considering these beliefs and opinions (Schulz, 2001). The aim of this study was to evaluate the digital literacy of a group of students who participated in a course on digital tools. The course was designed to introduce a variety of tools that are used for learning. As a fundamental objective, it was aimed to help students to evolve their digital literacy in a way that they can use their obtained skills and knowledge in the broader context of their future studies and career. The study also examines the effect of attending the course on students' attitudes toward technology and digital tools.

\section{Review of the Literature}

\subsection{Concept of Digital Literacy}

Digital literacy is a completely distinct concept from concepts like information literacy, computer literacy, ICT literacy, electronic literacy, network literacy, media literacy, and so forth. The concept was originally used by Gilster (1997) in his book. His definition of digital literacy is a general one and refers to the ability to understand and use information from a variety of digital sources. Although this definition is a simple definition of a multifaceted concept, it is noteworthy that it avoids providing long lists of technologies that are not constant and change all the time. Therefore, digital literacy should be seen as a way of thinking and understanding rather than the ability to understand and perform a series of technology-related tasks (Eshet, 2004). The concept of digital literacy as it was mentioned at the beginning, should be distinguished from other related concepts such as IT literacy, and computer literacy. In fact, the concept of IT literacy refers to a set of specific skills and abilities that refers to accessing and working on the information in a computerized format. Technological literacy in recent years has, of course, taken a wide range in addition to its skill-based denotative meaning, focusing on issues like the evaluation of information. Network literacy refers to digital information in a networked form that somehow resembles internet literacy. The concept of informacy encompasses traditional literacy and information literacy, or mediacy, which encompasses the ability to deal with information in a variety of media. According to Gilster, the four key competencies associated with digital literacy are internet search, hypertext navigation, information retrieval, and content evaluation. A comprehensive and preliminary definition of digital literacy that relates to the US library organization emphasizes elements such as identifying important information, locating information, accessing information, evaluating information, organizing information, and using information.

Eshet (2004) considers the digital literacy in the formal education environment as a set of literacies: visual literacy (visual comprehension); remix literacy (creative reuse of existing content); information literacy (related to evaluation of information); branching literacy (related to reading and understanding hypermedia); and socio-emotional literacy (mature and correct behavior in cyberspace). In another definition by European information society, digital literacy is considered as the knowledge, attitude, and ability of individuals to make appropriate use of digital capabilities and tools to identify, access, manage, integrate, evaluate, analyze, and combine digital resources, create new knowledge, create media terms, and communicate with others in the context of specific life situations in order to activate socially constructive actions as well as reflect on this process (Martin, 2005). In another definition, $\mathrm{Ng}$ (2012) considers digital literacy to include three dimensions of technical, cognitive, and socio-emotional. The technical dimension relates to the technical and operational skills that students need to use in their task of teaching. The cognitive dimension is a part of digital literacy that relates to students' ability to search, evaluate, and create digital information. This component includes knowledge and ability in techniques that assist in the retrieval, evaluation, interpretation, and production of information. The socio-emotional dimension of digital literacy is related to the responsible use of technology for communication, socializing and learning. This component discusses concepts such as network etiquette, internet security and privacy and management of threat.

\subsection{Review of the Related Literature}

Prensky (2001) claimed that the generation born after 1980 are digital natives. He characterized digital natives as multi-taskers who can quickly receive information from different sources and prefer one medium of information to another like graphics to texts. According to him, digital natives' lives revolve around writing blogs, spending time in online games, music download and upload, online purchase and sell, socializing online, using entertainment websites, and so forth. His argument about digital natives is similar to what is known as "baby boomer" (Jones, 1980) indicating that the generation of people born after a war is different from those born before the war. Jones characterized baby boomers as goal-oriented, competitive, and work-centric people. 
Even though most of the tenets of the digital nativity as proposed by Prensky have come under fire for example due to lack of evidence proving the existence of the difference in the structure of digital natives' brain, it is agreed that the generation born after the advent of computers generally possess unique skills. It is argued that these skills are mostly related to socializing and entertainment and do not include any educational tools. (Aziz, 2010) refers to educational tools as those which enhance the teaching and learning process. It seems that these so-called digital natives will not learn the educational use of these technologies unless they are exposed to them (Mahboudi, Farrokhi, \& Ansarin, 2017) and the responsibility of this important task falls on the shoulders of educators. The scaffolded ushering of this generation into using educational technologies is similar to supporting those who join a new community and need to learn their language in order to fulfill their responsibilities in the new community $(\mathrm{Ng}, 2012)$. Unlike learning the use of social networking and other entertainment tools which are largely peer-driven and learned through "tinkering, it is unlikely that digital natives would seek out, explore and use educational technologies unless they are introduced to them and/or there is a need to use them for a useful purpose (Ito et al., 2009). According to Ito et al. (2009) this extensive repertoire of skills that new generation displays, has mostly obtained through informal education. Following the impact of ICT on learning and study practices, there has also been an interest to explore the effect of educational use of technology on the experience of students at university (Edmunds, Thorpe, \& Conole, 2012). For example, Aydede, Kecercioğlu, and Arabacioğlu (2009) studied how the opinions of eight-grade students change after they attended a course on science and technology and found out that using computer technology in learning has a positive effect on students' attitudes. Simsek (2008) infused a course on reading with internet technologies in the EFL context and found a positive effect on students' attitudes. "Technology acceptance model," which was developed by Davis, Bagozzi, and Warshaw (1989) clearly illustrates the role of attitude in making our decisions and the factors that affect attitude:

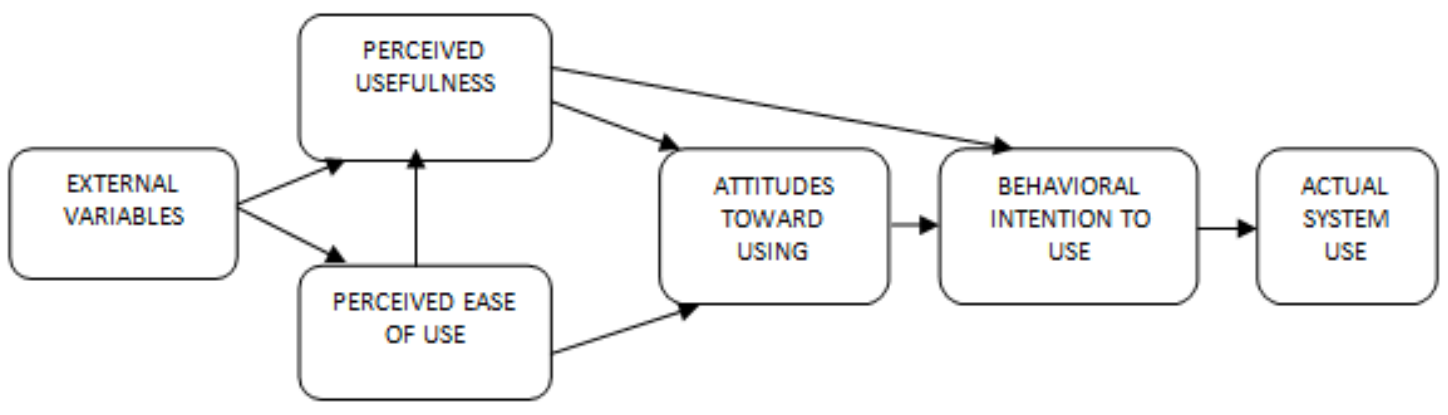

Figure-1. Technology Acceptance Model (Davis et al., 1989).

According to Figure 1 students will form a positive attitude toward educational technology and make a decision to actually integrate them in their learning and teaching tasks, only if they perceive them as useful and easy to use. The model is applicable to many areas of use including the educational and social application of technology. It is believed that a less positive attitude of teachers and prospective teachers contribute to their intendancy to use technology in Education. Yildirim (2000) states that if teachers maintain their negative attitude toward technology, they will not use them or encourage their students to do so in their classroom. Accordingly, Roblyer and Edwards (2000) express their concerns about prospective teachers who are still entering universities with a lack of computer literacy and inappropriate skills and have a concerningly low attitude toward technology use in the classrooms. It was hypothesized that a course on digital literacy will have an effect on students' digital literacy and attitude. The rationale behind the study was to fill the gap that exists in the literature in regard to the courses related to digital literacy. It was aimed to examine the effect of a one-month course in digital literacy on the participants' digital literacy knowledge and attitude toward educational technology. The following research questions were answered in this study:

1. Is there any significant difference in the digital literacy scores of the participants before and the treatment?

2. Is there any significant difference in participants' attitude before and after treatment?

\section{Method}

\subsection{Procedure}

This study aimed at examining the effect of a course titled "Introduction to digital literacy" on participants who attended the course in Kowsar institute in Bam. The course lasted for one month. The beginning and the last sessions were spent on the administration of pre and posttest respectively. As components of the course, there was an attempt to familiarize the participants with the different aspects of digital literacy as defined in the previous section that is technological, cognitive, and socio-emotional components. During the course of this one- month treatment, the necessary information was presented to students in weakly 90 minutes sessions. The course materials presented are shown in Table 1 distributed 
across different sessions. The classroom was in blended learning mode and participants were also required to share their completed projects after each session in a virtual classroom created in Edublogs by their instructor. The rationale for having this activity was to make sure that participants understand how they can use these digital tools in their learning. At the end of the course, they responded to the same set of questionnaires they answered in the pretest.

Table-1. Course syllabus.

\begin{tabular}{l|l}
\hline Session & Syllabus \\
\hline 1 & Introduction\& pretests \\
\hline 2 & Search the internet (search engine; operators; customizing; evaluating data, etc.) \\
\hline 3 & Weblogs; wikis; hyperlinks \\
\hline 4 & Presentation tools (e.g., PowerPoint) \\
\hline 5 & Making video clips ( e.g., using pro show) \\
\hline 6 & Connecting through web ( e.g., using Skype) \\
\hline 7 & Antiviruses \\
\hline 9 & Hyper Cam\& any desk tools \\
\hline 10 & Storing information clouds; RSS; tagging; netiquette \\
\hline
\end{tabular}

As Table 1 indicates, the course lasted for 10 sessions, all the participants attended the course on a regular basis and offered their complete cooperation except for three participants who gradually increased their absence from the sessions for personal reasons. Kosar al-Nabi institute, Bam branch, is a charity institute that manages free courses related to religion, arts, and sports. This institute operates all the time of the year, however, most of its activities are related to summer which coincide with school and university holidays in Iran. Prior to the beginning of the course, there was a discussion about the course and its aims with the institute and they agreed with offering the course in summer and took the responsibility of registering the interested participants.

Figure 2 represents the screenshot of a part of the course syllabus that was also uploaded in Edublogs to further support the learning of the participants. Participants were also allowed to share their posts.

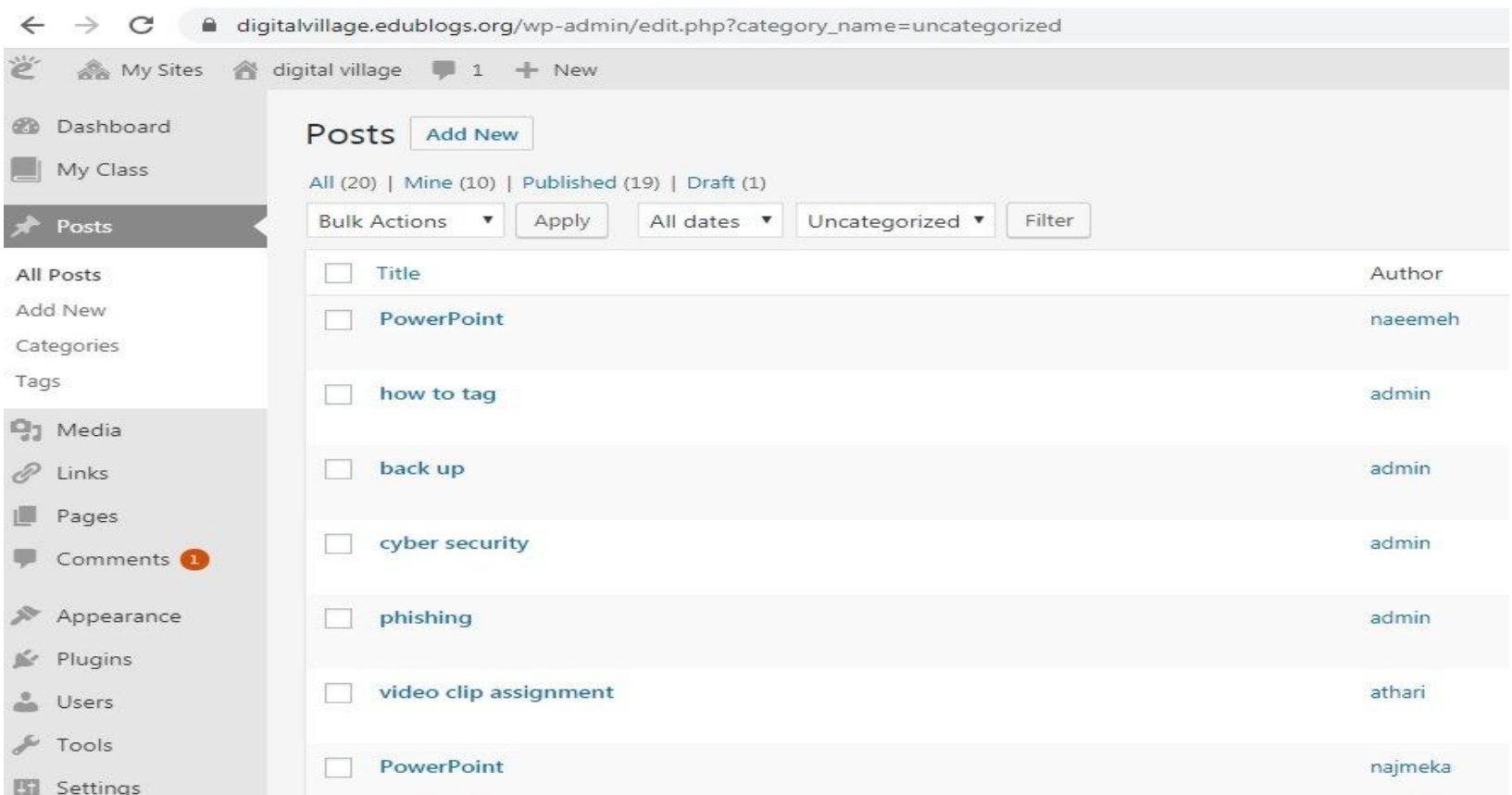

Figure-2. A Screenshot of a part of posts shared in "digital village" by either teacher or participants.

As Figure 2 represents, the researchers of the study created a class titled 'digital village' and added the participants of the study into this class. Both the researchers and their participants were able to share their posts in the classroom as well as write reflective comments on the shared posts. The researchers used to upload the course content into the virtual classroom in Edublogs prior to their actual classroom and give 
students some practical project following their class which they had to upload in the classroom. The comment feature of the Edublogs also allowed the participants to share their feelings, ideas, and questions about the shared content in the classroom. Figure 3 shows the log of the participants' posts about building a video clip project.

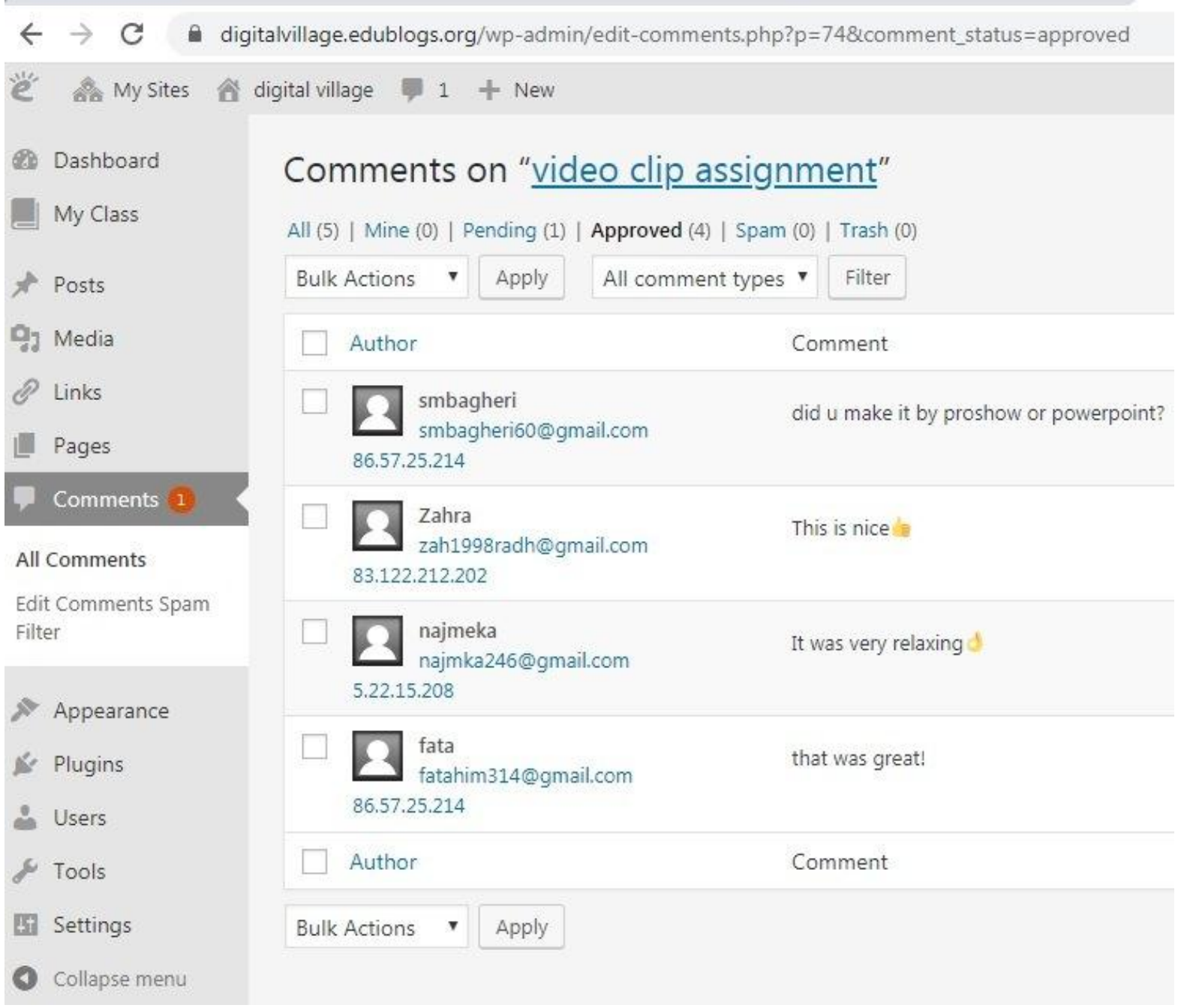

Figure-3. Participants' Comments on the Posts (Comments are given instead of the Typical Post with Following Comments to Observe Space Limit).

As Figure 3 indicates "digital village" classroom was a platform for the participants to showcase their digital artifacts and receive the comments from their teacher and the other students.

\subsection{Participants of the Study}

There were 13 participants in this study who were attending a summer school in the city of Bam, Kerman that is arranged by one of the charity organizations every year. All the participants were females and were living in this city at the time of the treatment. They were studying in different fields of study in different universities of the country. Table 2 gives some necessary descriptive information about the characteristics of the participants in this study.

Table-2. Descriptive Information of Participants

\begin{tabular}{l|l|c|c}
\hline Age & Year in University & Access to Digital Tools & IT Background \\
\hline 23.91 & Freshman (10\%) & $2(75 \%)$ & Yes $(30 \%)$ \\
\hline & Sophomore (50\%) & $3(25 \%)$ & No $(70 \%)$ \\
\hline & Junior $(30 \%)$ & $100 \%$ & $100 \%$ \\
\hline & Senior $(10 \%)$ & & \\
\hline & $100 \%$ & & \\
\hline
\end{tabular}


According to Table 2 the average age of the participants was 23.91 years old. A review of their admission year to university indicates that $10 \%$ of the participants were in the first year of their undergraduate studies. Most of the participants were studying the second year of their studies (50\%), and the third and fourth-year students were $30 \%$ and $10 \%$ respectively. Regarding access to digital tools, most of the participants $(75 \%)$ stated that they had access to 2 digital tools, while the participants using 3 digital tools were $25 \%$. In response to a question related to their experience with technology, $30 \%$ of the participants have previously attended some courses or workshops in technology, however, most of them (70\%) did not mention having such experience.

\subsection{Instruments}

The digital literacy questionnaire was adapted from $\mathrm{Ng}$ (2012) was used as the pretest and posttest. The questionnaire consisted of three components of technological, cognitive, and socio-emotional. Items in the questionnaire were Likert type with five options ranging from 1 "not true of me," to 5 "true of me." Table 3 represents different dimensions of digital literacy with example statements.

\begin{tabular}{l|l|l}
\multicolumn{2}{c}{ Table-3. Digital literacy questionnaire across three components with example representing statements. } \\
\hline Technical & Cognitive & Socio-Emotional \\
\hline $\begin{array}{l}\text { 1. I can set up a personal } \\
\text { blog or a wiki (using } \\
\text { websites such as Mahan } \\
\text { Blog, Blogfa, etc.) }\end{array}$ & $\begin{array}{l}\text { 24. I can get the information I want from } \\
\text { the search results ( i.e., I do no get } \\
\text { confused by the amount of information). }\end{array}$ & $\begin{array}{l}\text { 39. I can maintain my positive } \\
\text { image in the online environment } \\
\text { (for example, by avoiding the } \\
\text { sharing of unpleasant posts or my } \\
\text { own images and others). }\end{array}$ \\
\hline $\begin{array}{l}\text { 2. I can create different } \\
\text { types of online texts (e.g. } \\
\text { blog posts, status updates, } \\
\text { tweets, etc.). }\end{array}$ & $\begin{array}{l}\text { 26. When I read an online text, I can an informed decision about the } \\
\text { hyperlinks in the text that I want to visit. }\end{array}$ & $\begin{array}{l}\text { 34. I understand the importance of } \\
\text { selecting an appropriate user ID } \\
\text { for social networking websites and } \\
\text { how it reflects who I am. }\end{array}$ \\
$\begin{array}{l}\text { 17. I can edit video clips } \\
\text { on my computer or } \\
\text { mobile. }\end{array}$ & $\begin{array}{l}\text { 25. I often review the information to make } \\
\text { sure that what I share or comment on is } \\
\text { valid. }\end{array}$ & $\begin{array}{l}\text { 43. When I join an online } \\
\text { discussion, I respect others and } \\
\text { their comments }\end{array}$ \\
\hline
\end{tabular}

Two colleagues with an expertise in ICT education validated the questionnaire which was introduced in Table 3 and used as one of the instruments. According to the schedule, the first week was arranged for the pretest. The digital literacy questionnaire composed of two parts: the first part was related to digital literacy and the second part asked questions about demographic information. The second administration of the questionnaire occurred in the last week of the course. The content of the course was related to issues like the capacity of technology, planning the content and creation of products using the technology.

In addition, the attitude questionnaire used in this study consisted of 20 questions and was adopted from Edmunds et al. (2012) which focused on evaluating the impact of a course on how students perceive technology as useful and easy to use. The questionnaire, itself, is an adaptation of a well-established questionnaire in the field (Davis et al., 1989) about factors contributing to resistance to technology use. To respond to the statements in the questionnaire, students needed to choose from a scale of 1-5 representing their strong agreement to strong disagreement with the statements. Psychometric characteristics of the questionnaire like validity and reliability have profusely reported by many studies to exceed standard values. Table 4 represents some of the items of the questionnaire under two component factors of usefulness and ease of use.

Table-4. Factors of the questionnaire along with representing statements.

\begin{tabular}{l|l|l|l}
\hline$\#$ & Usefulness & $\#$ & Ease of use \\
\hline 1 & learning is made easier by using ICT & 16 & ICI is generally easy to use on my course \\
\hline 3 & ICT makes me a more effective learner & 15 & $\begin{array}{l}\text { I find ICT easy to learn to use on my } \\
\text { course }\end{array}$ \\
\hline 9 & ICI allows me to produce more in the time I have & 18 & $\begin{array}{l}\text { I find it easy to become skillful in using } \\
\text { ICT on my course }\end{array}$ \\
\hline 11 & ICT is useful as a learning tool & 17 & $\begin{array}{l}\text { I can control ICT and make it do what I } \\
\text { want on my course }\end{array}$ \\
\hline
\end{tabular}

\section{Results}

To analyze data in this study, the statistical package for social sciences (SPSS), version 18 was used. First descriptive statistics were obtained to give information like means and standard deviations. Inferential statistics were also used to examine the existence of any significant difference in attitude and digital literacy between pre and posttest. 
In order to evaluate the effect of the course in digital literacy on the participants, a paired samples t-test was conducted to examine the existence of a significant change in the participants' digital literacy before and after the treatment. Table 5 and Table 6 represents the results of this analysis.

Table-5. Paired samples statistics.

\begin{tabular}{l|l|l|l|l|l}
\hline \multicolumn{2}{c|}{} & Mean & N & Std. Deviation & Std. Error Mean \\
\hline \multirow{2}{*}{ Pair 1} & Predigital & 2.42 & 13 & 0.6 & 0.16 \\
\cline { 2 - 6 } & Postdigital & 4.39 & 13 & 0.24 & 0.07 \\
\hline
\end{tabular}

Table-6. Paired Samples Test.

\begin{tabular}{|c|c|c|c|c|c|c|c|c|c|}
\hline & & \multicolumn{5}{|c|}{ Paired Differences } & \multirow{3}{*}{$\mathbf{t}$} & \multirow{3}{*}{ df } & \multirow{3}{*}{$\begin{array}{l}\text { Sig. (2- } \\
\text { tailed) }\end{array}$} \\
\hline & & \multirow[t]{2}{*}{ Mean } & \multirow[t]{2}{*}{$\begin{array}{l}\text { Std. } \\
\text { Deviation }\end{array}$} & \multirow{2}{*}{$\begin{array}{l}\text { Std. } \\
\text { Error } \\
\text { Mean }\end{array}$} & \multicolumn{2}{|c|}{$\begin{array}{l}95 \% \text { Confidence } \\
\text { Interval of the } \\
\text { Difference }\end{array}$} & & & \\
\hline & & & & & Lower & Upper & & & \\
\hline Pair 1 & $\begin{array}{l}\text { Predigital } \\
- \\
\text { Postdigital }\end{array}$ & -1.97 & 0.56 & 0.16 & -2.31 & -1.63 & -12.58 & 12 & $\mathrm{O}$ \\
\hline
\end{tabular}

According to Table 5 there was a statistically significant increase in the mean of digital literacy score from pretest $(\mathrm{M}=2.4, \mathrm{SD}=0.60)$ to post test $(M=4.39, S D=0.24), \mathrm{t}(12)=-12.578, \mathrm{p}<.000$ (two-tailed). The mean decrease in digital literacy scores was 1.97 with a $95 \%$ confidence interval ranging from 2.31 to 1.63 . The eta squared statistic (0.93) indicated a large effect size.

In order to evaluate the effect of the course on students' attitudes toward the educational use of the technology, after administrating the attitude questionnaire to the participants, the difference in mean of the participants' attitude in pretest and posttest was analyzed for the existence of any significant difference. The results of the analysis through a paired samples t-test are represented in Table 7 and Table 8:

\begin{tabular}{l|l|l|l|l|l}
\hline \multicolumn{2}{c|}{} & Mean & N & Std. Deviation & $\begin{array}{l}\text { Std. } \\
\text { Mean }\end{array}$ \\
\hline \multirow{2}{*}{ Pair 1 } & AttPre & 4.64 & 9 & 0.30 & 0.10 \\
\cline { 2 - 7 } & attiPOS & 4.88 & 9 & 0.21 & 0.10 \\
\hline
\end{tabular}

Table-8. Paired samples test.

\begin{tabular}{|c|c|c|c|c|c|c|c|c|c|}
\hline & & \multicolumn{5}{|c|}{ Paired Differences } & \multirow[b]{3}{*}{$\mathbf{t}$} & \multirow[b]{3}{*}{ df } & \multirow{3}{*}{$\begin{array}{l}\text { Sig. } \\
\text { (2- } \\
\text { taile } \\
\text { d) }\end{array}$} \\
\hline & & \multirow[b]{2}{*}{ Mean } & \multirow{2}{*}{$\begin{array}{l}\text { Std. } \\
\text { Deviation }\end{array}$} & \multirow{2}{*}{$\begin{array}{l}\text { Std. Error } \\
\text { Mean }\end{array}$} & \multicolumn{2}{|c|}{$\begin{array}{l}95 \% \text { Confidence } \\
\text { Interval of the } \\
\text { Difference }\end{array}$} & & & \\
\hline & & & & & Lower & Upper & & & \\
\hline $\begin{array}{l}\text { Pair } \\
1\end{array}$ & $\begin{array}{l}\text { AttPre - } \\
\text { attiPOS }\end{array}$ & -0.25 & 0.16 & 0.05 & -0.37 & -0.12 & -4.54 & 8 & 0.00 \\
\hline
\end{tabular}

According to Table 7 there was a statistically significant increase in the mean of the participants' attitude score from pretest $(\mathrm{M}=4.64, \mathrm{SD}=0.30)$ to post test $(M=4.88, S D=0.21), \mathrm{t}(8)=4.54, \mathrm{p}<0.00$ (two-tailed). The mean increase in digital literacy scores was 0.25 with a $95 \%$ confidence interval ranging from 0.37 to 0.12 . The eta squared statistic $(0.72)$ indicated a large effect size.

\section{Discussion}

The first research question investigated the existence of a significant difference in the mean scores of digital literacy before and after the attendance in the course. The finding shows that participants significantly improved their digital literacy. In accordance with $\mathrm{Ng}$ (2012) this result can be explained by the fact that the majority of new students never consider using unfamiliar technology as the major problem. They are gifted with the ability to concurrently learn about new technology, plan their content, and create new artifacts. This 
finding also supports the argument by Mahboudi et al. (2017) in that technology will not be used for education unless educators illustrate the using of these technologies. Considering the study by Davis et al. (1989) where it was found that usefulness of technology is a stronger predictor of technology use than functionality and easiness of use, it can be argued that due to inherent characteristics of new generation, they usually do not report facing any problems in learning new technology and it seems that the only factor that will guarantee the future use of these technologies in different domains like socializing, work, or education is perceiving of these technologies as useful devices, so, it is in this context that the argument made by some of the researchers like (Mahboudi et al., 2017) is justified as they call educators to usher and lead educational use of these technologies among students and prospective teachers. It seems that the act of attending the course increased participants' knowledge about the scope of digital literacy and encouraged metacognition among subjects as they reflected on their actual use of technology. The second research question asked about the attitude of the participants about using technology. The result of the analysis indicated a positive and significant increase in the learners' attitude toward using technology. The findings of this study support the findings of Aydede et al. (2009) and Simsek (2008) in that actual demonstration of how technology is used in learning through a course will positively affect learners' attitude. According to the technology acceptance model as discussed in the review of the literature, familiarizing learners with the effectiveness and easiness of use of technology will, in turn, have a positive impact on attitudes which ultimately culminate in the actual use of technology.

\section{Conclusion and Implications}

This study sought to examine the digital literacy level and attitude of a group of participants who attended a one-month course in digital literacy. The researchers of the study wanted to see if the level of digital literacy of these students would increase as the result of their attendance in the course. The framework of digital literacy education in this course included three dimensions of technical, cognitive, and socialemotional. Participants also evaluated the role of explicit teaching and learning in increasing the digital literacy level of students. The findings of this study indicated that explicit instruction allows educators to draw learners' attention to educational technologies as well as change their attitudes toward the pedagogical application of these tools. It is suggested that future studies can focus on each one of the tools related to technological components separately and evaluate their pedagogical benefits. They can also embark upon educating learners exclusively about the other components of digital literacy that are cognitive and socioemotional. One limitation of this study may be the use of a self-report questionnaire which does not measure actual behavior because people are not always able to report their competence accurately. Even though in this study, participants uploaded their projects into their edublogs which indicate their uptake of the course content, the future studies can integrate learners' actual behavior into their method as a means of collecting information.

\section{References}

Aydede, M. N., Kecercioğlu, T., \& Arabacioğlu, S. (2009). The opinions of students regarding the usage of computer technologies in constructivist learning. Procedia-Social and Behavioral Sciences, 1(1), 2763-2767.Available at: https://doi.org/10.1016/j.sbspro.2009.01.490.

Aziz, H. (2010). The 5 keys to educational technology. Transforming education through technology. Retrieved from: http://thejournal.com/articles/2010/09/16/the-5-keys-to-educational-technology.aspx.

Davis, F. D., Bagozzi, R. P., \& Warshaw, P. R. (1989). User acceptance of computer technology: A comparison of two theoretical models. Management Science, 35(8), 982-1003.

Edmunds, R., Thorpe, M., \& Conole, G. (2012). Student attitudes towards and use of ICT in course study, work and social activity: A technology acceptance model approach. British Journal of Educational Technology, 43(1), 7184.Available at: https://doi.org/10.1111/j.1467-8535.2010.01142.x.

Eshet, Y. (2004). Digital literacy: A conceptual framework for survival skills in the digital era. Journal of Educational Multimedia and Hypermedia, 13(1), 93-106.

Gilster, P. (1997). Digital literacy. New York: Wiley Computer Publication.

Howe, N., \& Strauss, W. (2009). Millennials rising: The next great generation. New York: Vintage.

Inoue, H., Naito, E., \& Koshizuka, M. (1997). Mediacy: What it is? Where to go? The International Information \& Library Review, 29(3-4), 403-413.Available at: https://doi.org/10.1080/10572317.1997.10762448.

Ito, M., Horst, H. A., Bittanti, M., Stephenson, B. H., Lange, P. G., Pascoe, C., \& Mahendran, D. (2009). Living and learning with new media: Summary of findings from the Digital Youth Project: MIT Press.

Jones, L. (1980). Great expectations: America and the baby boom generation. New York: Coward, McCann \& Geoghegan.

Kalaja, P., \& Ferreira, A. M. B. (2003). Beliefs about SLA: New research approaches. New York: Springer.

Lenhart, A., Rainie, L., \& Lewis, O. (2001). Teenage life online: The rise of the instant-message generation and the Internet's impact on friendships and family relationships. Washington, DC: Pew Internet \& American Life Project.

Mahboudi, H. R., Farrokhi, F., \& Ansarin, A. A. (2017). A review on application of computers in education inside and outside of Iran. Advances in Language and Literary Studies, 8(4), 29-42.Available at: https://doi.org/10.7575/aiac.alls.v.8n.4p.29.

Martin, A. (2005). DigEuLit-a European framework for digital literacy: A progress report. Journal of eLiteracy, 2(2), 130136.

McClure, C. R. (1994). Network literacy: A role for libraries? Information Technology and Libraries, 13(2), 115-126. 
Neelameghan, A. (1995). Literacy, numeracy informacy. Information Studies, 1(4), 239-249.

Ng, W. (2012). Can we teach digital natives digital literacy? Computers \& Education, 59(3), 1065-1078.Available at: https://doi.org/10.1016/j.compedu.2012.04.016.

Oblinger, D., \& Oblinger, J. L. (2005). Educating the net generation. Boulder, Colo: Ducause.

Pedró, F. (2007). The new millennium learners: Challenging our views on digital technologies and learning. Nordic Journal of Digital Literacy, 2(04), 244-264.

Prensky, M. (2001). Digital natives, digital immigrants part 1. On the Horizon, 9(5), 1-6.

Roblyer, M. C., \& Edwards, J. (2000). Integrating technology into teaching. New Jersey: Prentice-Hall.

Schulz, R. A. (2001). Cultural differences in student and teacher perceptions concerning the role of grammar instruction and corrective feedback: USA- Colombia. The Modern Language Journal, 85(2), 244-258.Available at: https://doi.org/10.1111/0026-7902.00107.

Simsek, C. S. (2008). Students' attitudes towards integration of ICTs in a reading course: A case in Turkey. Computers $\mathcal{E}^{\circ}$ Education, 51(1), 200-211.Available at: https://doi.org/10.1016/j.compedu.2007.05.002.

Tapscott, D. (2008). Grown up digital: How the net generation is changing your world. New York: McGraw-Hill.

Veen, W., \& Vrakking, B. (2006). Homo zappiens: Growing up in a digital age. London: Network Continuum Education.

Yildirim, S. (2000). Effects of an educational computing course on preservice and inservice teachers: A discussion and analysis of attitudes and use. Journal of Research on computing in Education, 32(4), 479-495.Available at: https://doi.org/10.1080/08886504.2000.10782293. 